\title{
ANALYSIS OF PREDICTION METHODS APPLIED TO A SELECTED ROAD VEHICLE TRACING SYSTEM
}

The system which is developed in Department of Transport and Electrical Engineering UTH Rad. consists of collecting, analyzing and selecting data from existing observation units, and such to be installed in the future, including photo-radars, electronic fee collection and traffic monitoring cameras. The aim is tracking of objects distinguished by certain visual features. The present paper specifies the road net on chosen area and further, algorithms for the prediction of the continuations of vehicle tracks registered by the system are on consideration and assessed.

\section{INTRODUCTION}

Successively developed in the Faculty of Transport and Electrical Engineering UTH Rad. and presented in the series of articles i.a. [1-8], the concept of the Road Vehicle Tracking System Based on Given Identification Features (called RETINA) has been extended to include subsequent stages. Various approaches to the subject of prediction are considered, and the research area has been narrowed down to selected roads of the Masovian voivodeship.

\section{SCHEME OF A CHOSEN SYSTEM}

When designing the RETINA system, it is assumed that the object of interest is optically recognized on the basis of information obtained from observation points, in which the cameras are monitoring the roads together with additional properly-programmed equipment and transmitters/receivers of selected telecommunication systems.

The registration of this event is transmitted wirelessly to the Observatory, where the data is processed. They will be used to reconstruct the trajectory of a given vehicle for short-term prediction of its further route. Of course, the larger the number of so-called visions, the better the quality of prediction, which will be used to support the interested, legitimate intervention forces.

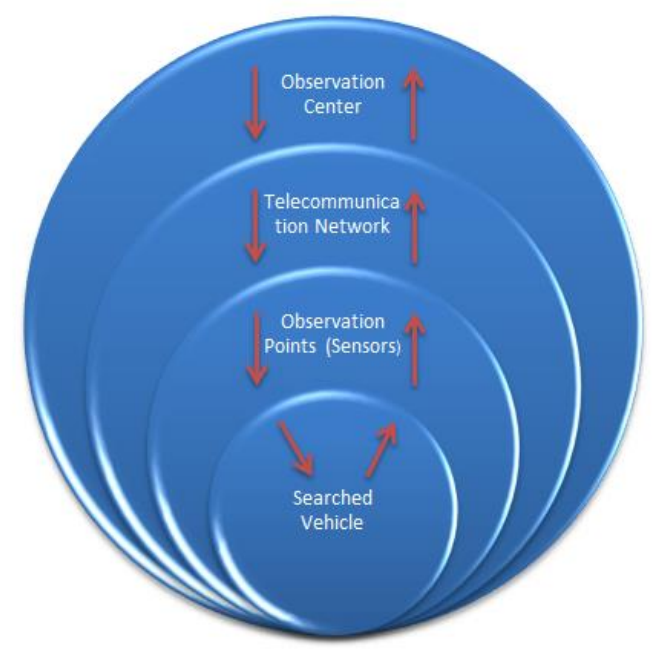

Fig. 1. Diagram of the system operation
An important factor for the effective operation of the network is two-way communication between the sensors and the Observatory, where the list of vehicles is updated. Figure 1 illustrates the system's structure.

\section{PREDICTION METHODS}

The operation of linear prediction can be generalized by dividing into the following stages - arranging events recorded in the table, conducting regression, extending into the (nearby) future. Detailed description and test results can be found in publication [3]. A problem arises in the designed system - taking into account the road network - the regression line does not lie in the system of roads included in the model. So, the route is extended to the segments closest to the simple prediction. However, this method has disadvantages: - apart from geometry - it does not include the population of the area, the existence of agglomerations, less-frequented areas or densely populated areas.

An alternative is the decision tree, taking into account all possible branches on each subsequent node [12]. The probabilities of choosing individual blocks based on traffic values are used, for example: "Rondo Narodowych Sił Zbrojnych" - the roundabout in Radom, marked in the figure below by 0 , as in [2]. Possible driving directions (branches) are defined as follows: W - Warszawa (Warsaw), K - Kraków (Cracow), R Rzeszów (or/and the center of Radom) and $L$ - Lublin.

For a representative day of the week, Wednesday was accepted, and on this day, traffic intensity tests were carried out at around noon. Such a choice was made in order to exclude additional complications related to the need to take into account further factors such as immigration of migrants from the capital city of Warsaw (100km away) on non-working days or perturbations related to the Regulation of the Minister of Transport of July 31, 2007 on Periodic restrictions and prohibitions on the movement of certain vehicles on roads (Journal of Laws 147 item 1040 of 2007 , as amended). 


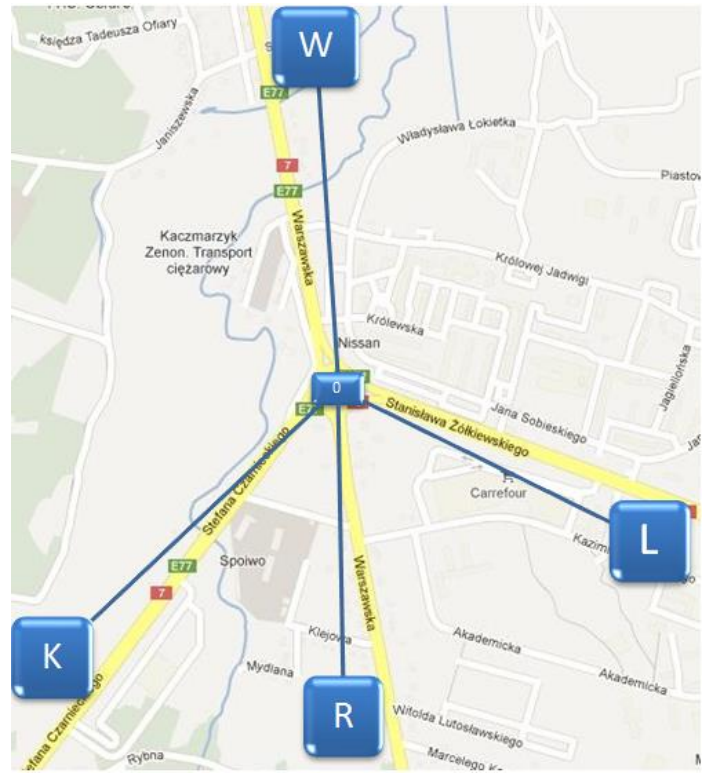

Fig. 2. Location of empirical research - "Rondo Narodowych Sit Zbrojnych" (the roundabout in Radom)

Thanks to the empirical study of the traffic, the shares of vehicles driving in particular directions $K, R, L$ or $W$ for each of the entries were known, which was presented using the histograms in Figure 3.

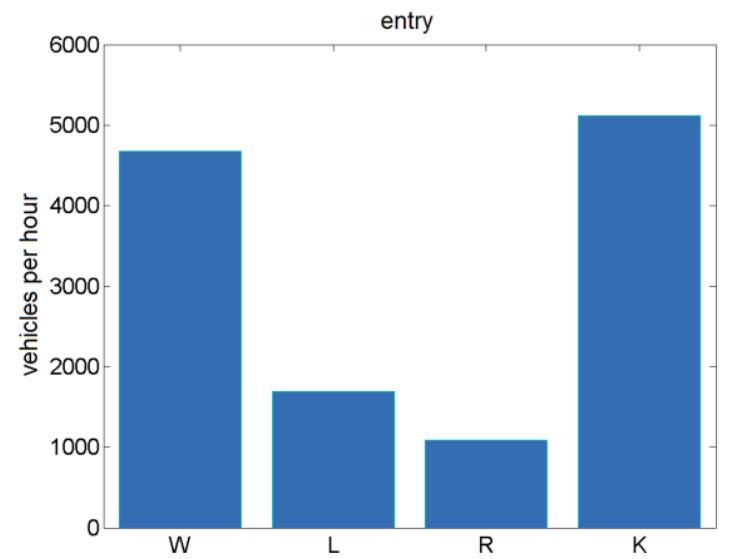

Fig. 3. Traffic intensity on individual entries to the roundabout

The relation of traffic loads on these entries was also recorded and hence the load on trips was calculated as shown in Figure 4.

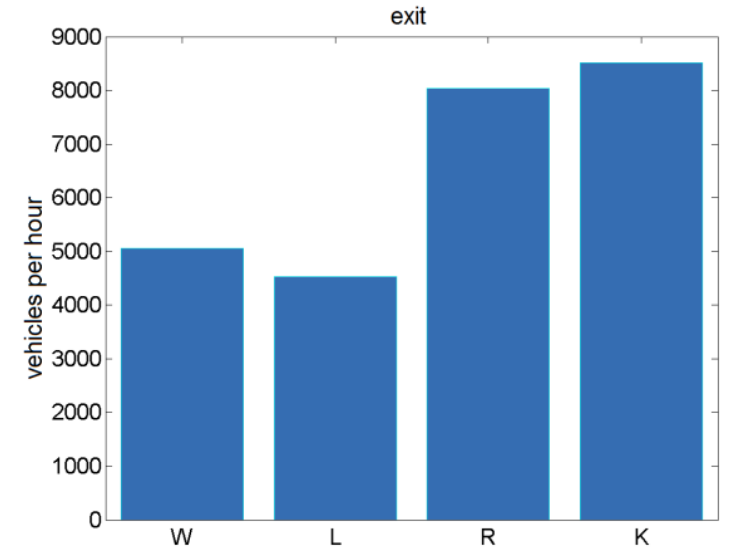

Fig. 4. The intensity of traffic on individual trips from the roundabout
These shares form a square matrix, which can be conveniently visualized with a three-dimensional beam diagram (Figure 3).

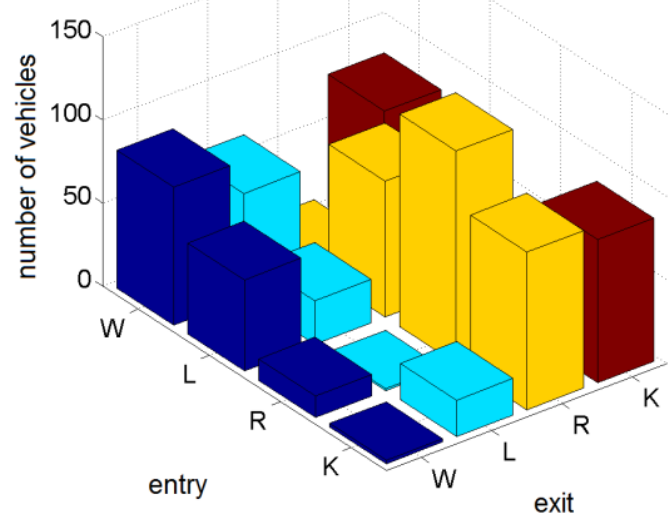

Fig. 3. Share of cars with the division into entry and exit from the roundabout

Knowing the intensity of traffic on a particular node, it is possible to predict the route of the monitored car. However, the disadvantage of this solution is quite rapid diffusion. After a few time steps, the area of possible positions of the monitored vehicle becomes too large to be useful.

In simulation studies, for example, the road network of the Mazovia voivodeship is shown in Figure 4.

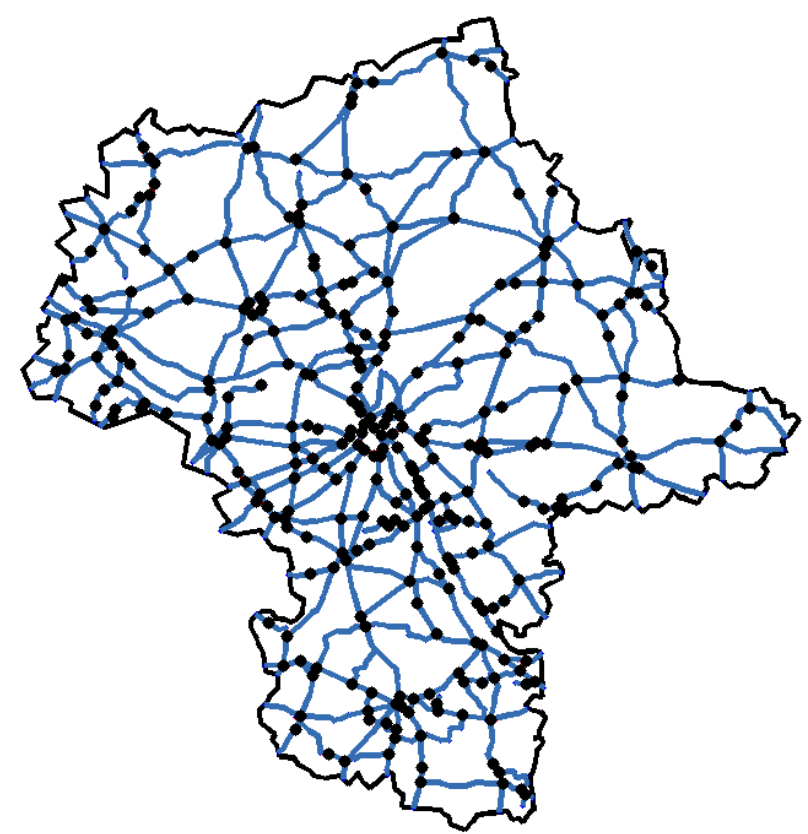

Fig. 4. Mazovian road network in the form of a graph

In the next step, the selection of the start and destination was made [11]. To illustrate the operation of the whole procedure two extreme points are given as an example - the northernmost and the southernmost of Mazovia. The program using the backward propagation algorithm (the course marked in black in Figure 5) calculates the distances between vertices, thus systematically assigning weights to the next edges. 


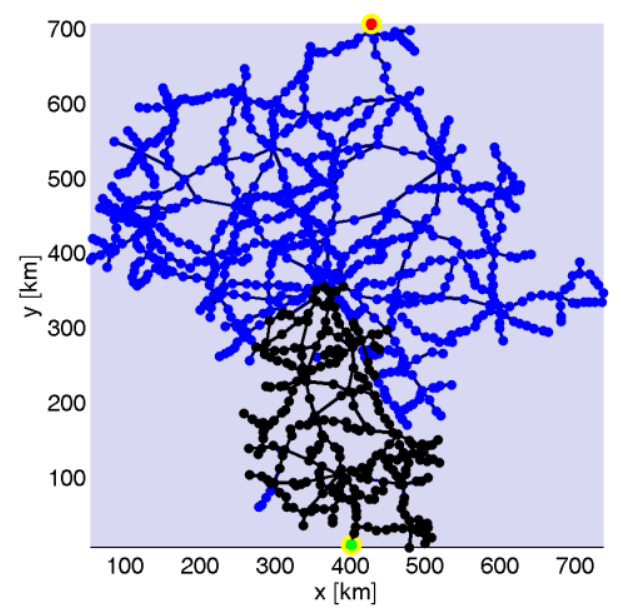

Fig. 5. Backward propagation on the graph visualizing road net on Masovian voivodeship

Then, using the optimization method of steepest descent, the shortest route between the set points is calculated, marked in cyan with the color in Figure 6.

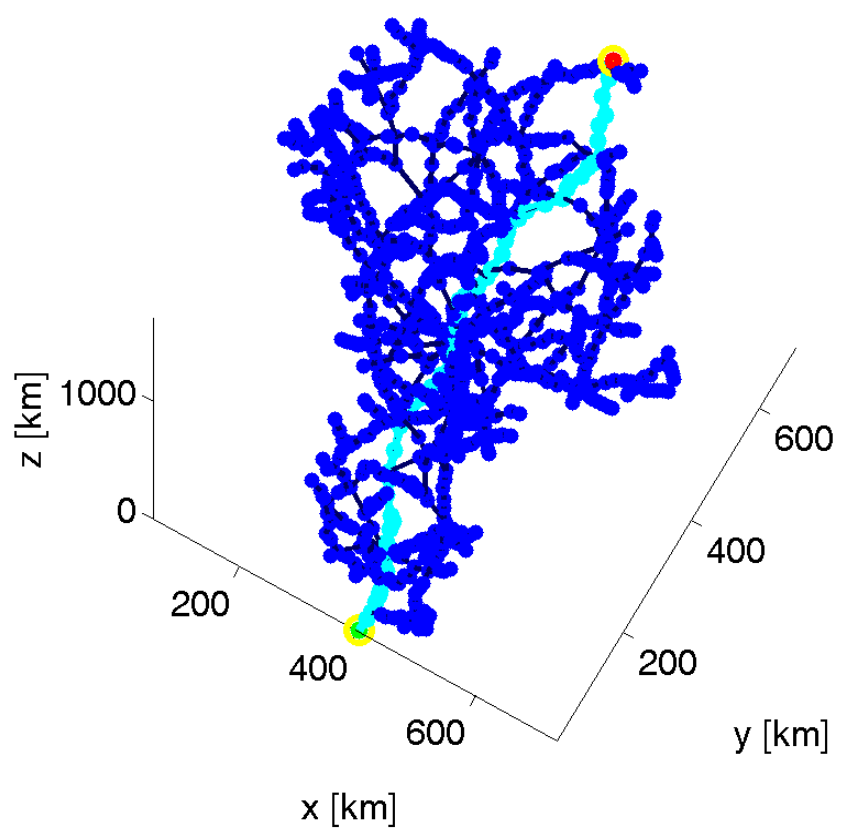

Fig. 6. Optimized using method of steepest descent

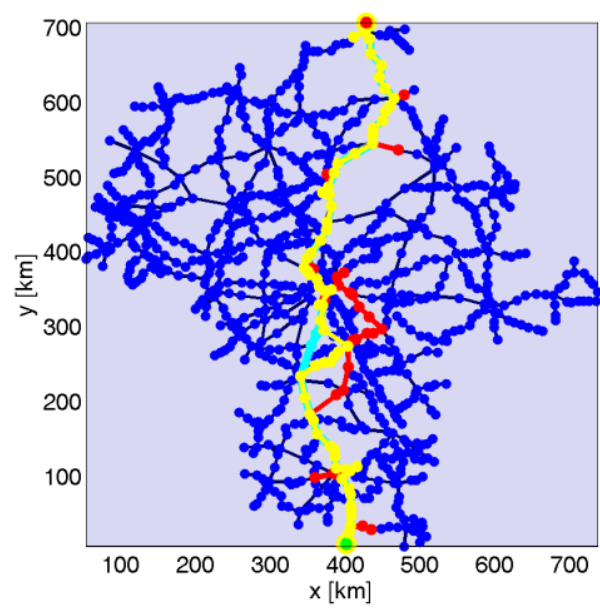

Fig. 7. Sample courses of simulated trajectories on the graph visualizing the Mazovian roads
As a result of the activities described above, the optimal length of the route is obtained, assuming that the searched object moves towards the south. Figure 7 shows three sample routes of the vehicle.

\section{ALTERNATIVE METHOD}

Another alternative is the prediction based on the Bayes approach. The system being developed initially determines the initial probabilities of the vehicle's destination, based on the density of the road network around the nodes. Each subsequent visual registration of the object of interest updates the ranking of probabilities. Simultaneously, a further vehicle route is simulated, assuming that the driver's goal is another node from the list of the most likely destinations. In the event of a good chance of an accurate forecast of the arrival of the monitored vehicle to a particular node, the Observation Center may decide whether the intervention forces should be directed (depending on the purpose for which the vehicle is being observed).

In simulation studies of the designed system assuming that no optical registration of the given vehicle has taken place, it is considered that the a priori probability distribution to which of the grid nodes he is following is known. It was called $\mathrm{Pa}$. This distribution can be based on statistical data - on population density of the studied area or traffic volume on particular road sections. This type of data can be obtained, for example, from publicly available results of operations regularly posted on the official website of the Central Statistical Office.

After the first registration of the vehicle, its direction of traffic is known. Such information is provided by the observation point, based on the optical verification - which traffic lane the monitored object was moving around. Such message significantly reduces the probability that the car travels to nodes that remain in its back, and increases the probability of places further in the direction of its travel.

After each subsequent appearance of the car at the observation point, the set of probable destinations can be successively narrowed. All those that are inconsistent with the decision to choose sections of the driver's route will be sequentially reduced.

It is not possible to predict the ending point of the trajectory of the vehicle in this way - it can stop at any point, turn or turn back, but you can determine its most likely communication routes.

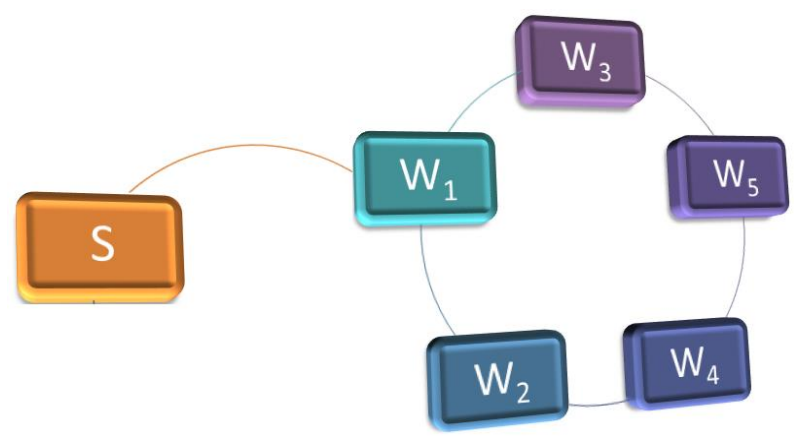

Fig. 8. An example of a graph

In figure 8 the $S$ car is shown before the road branching. The probability a priori that its aim is the node $W_{j}$ is $P_{j}$, and the sum of probabilities $P_{j}$ - is equal to 1 . In cases where the target is $W_{3}$ or $W_{5}$, leaving the node $W_{1}$ towards $W_{2}$ is unlikely, while for the destination $W_{2}$ or $W_{4}$ the choice is almost certain. In the 
opposite way, the twist on $W_{3}$ should be assessed - depending on the proper final destination $[9,10]$.

It is obvious that the driver can incorrectly turn wrong or deliberately choose a detour for unknown reasons. Hence the residual risk that the application is wrong.

Assuming that the goal is $W_{4}$, the Bayesian Theorem will be:

$$
\begin{gathered}
P\left(W_{4} \mid W_{2}\right)=\frac{P\left(W_{4} \cap W_{2}\right)}{P\left(W_{2}\right)} \\
P\left(W_{2}\right)=\sum_{j=1}^{5} P\left(W_{2} \mid W_{j}\right) P\left(W_{j}\right)
\end{gathered}
$$

The presented method finds application in transport problems, and its results in research on the RETINA system will be presented in the nearest publications.

\section{SUMMARY}

This article presents an outline of the operation of the RETINA system being developed (Road Vehicle Tracking System Based on Given Identification Features). The results of research on alternative prediction methods were presented, their advantages and disadvantages were discussed, their effects were demonstrated on real objects, such as "Rondo Narodowych Sił Zbrojnych" - the roundabout in Radom, and their effects were simulated on a network of selected Mazovian roads - a testing ground with a graph structure, whose vertices are intersections and the edges - road sections. The concept of applying the Bayesian Theorem, which results will be presented in subsequent studies, was also presented.

\section{BIBLIOGRAFIA}

1. Górska M., Application of dash-cams in road vehicle location systems. Czasopismo Autobusy - Technika, Eksploatacja, Systemy Transportowe 2017, nr 12, pp. 122-126

2. Górska M., Jackowski S., Wybrane techniki sieciowej obserwacji ruchu pojazdu drogowego. Czasopismo TTS - Technika Transportu Szynowego 2012, nr 9, pp. 2055-2062

3. Górska M., Metody matematyczne ekstrapolacji trajektorii ruchu pojazdów drogowych. Czasopismo TTS - Technika Transportu Szynowego 2012, nr 9, pp. 4201-4211

4. Górska M., Jackowski J., Analiza wybranych czynników wpływających na trajektorie ruchu poszukiwanych pojazdów. Czasopismo Logistyka 2012, nr 3. pp. 669-676

5. Górska M., Jackowski S., Optymalizacja sieci inteligentnych obserwatorów. Czasopismo Logistyka 2011, nr 6, pp. 1177 1186
6. Górska M., Assessment of observer positions for given behavior of drivers. Czasopismo Logistyka 2011, nr 6, pp. 1187-1196

7. Górska M., Tracing multiple mobile objects by a network of intelligent detectors. Czasopismo Logistyka 2011, nr 3, pp. 747754

8. Górska M., Course prediction for mobile object tracing network. Proceedings of the 4th International Interdisciplinary Technical Conference of Young Scientists, Poznań 2011, pp. 148-152

9. Grabski F., Jaźwiński J., Metody Bayesowskie w niezawodności i diagnostyce z przykładami. Wydawnictwa Komunikacji i Łączności, Warszawa 2001.

10. Grzenda W., Wstęp do statystyki Bayesowskiej. Oficyna Wydawnicza - Szkoła Główna Handlowa w Warszawie, Warszawa 2012.

11. Hudert S., Niemann C., Eymann T., On Computer Simulation as a Component in Information Systems Research. Lecture Notes in Computer Science, Vol. 6105, Global Perspectives on Design Science Research, str. 167-179, 2010.

12. Sohn J.H., Baek W.K., Vehicle dynamic simulation including an artificial neural network bushing model. Journal of Mechanical Science and Technology, Vol.19, nr 1, str. 255-264, 2005.

\section{Analiza metod predykcji trajektorii pojazdów drogowych zastosowanych w wybranym systemie poszukiwania}

Działanie opracowywanego na Wydziale Transportu i Elektrotechniki UTH Rad. systemu poszukiwania pojazdów drogowych polega na kolekcji, analizie i selekcji danych uzyskanych z różnorodnych istniejących, a także dodatkowo zainstalowanych jednostek obserwacyjnych takich jak fotoradary, kamery monitorujace ruch uliczny lub bramki stuzace do automatycznego poboru opłat. Celem jest śledzenie obiektów o zadanych cechach dystynktywnych. W niniejszym artykule sprecyzowano sieć dróg na zadanym obszarze, a następnie rozpatrywane $i$ oceniane sa algorytmy predykcji dalszych tras obiektów - pojazdów drogowych, które zostaly zanotowane przez system.

Autorzy:

prof. dr hab. inż. Zbigniew Łukasik - Uniwersytet Technologiczno-Humanistyczny im. K. Pułaskiego w Radomiu, Wydział Transportu i Elektrotechniki

dr inż. Małgorzata Górska - Uniwersytet TechnologicznoHumanistyczny im. K. Pułaskiego w Radomiu, Wydział Transportu i Elektrotechniki

JEL: 018 DOI: 10.24136/atest.2018.201

Data zgłoszenia: 2018.05.25 Data akceptacji: 2018.06.15 